\title{
Iowa Historical Records Advisory Board State Historical Records Plan July 1976
}

Early in 1976 the National Historical Publications and Records Commission approved of the composition of the Iowa Historical Records Advisory Board as nominated by Governor Robert D. Ray. The latter body exists to further the preservation and use of historical records and to assist the NHPRC in the generation, evaluation, and monitoring of grant applications relevant to historical records in Iowa. Last summer the IHRAB formulated the following plan to give some direction to its early efforts. The plan will be revised and updated in subsequent years.

For further information about the IHRAB and instructions on how to proceed with grant applications contact:

Dr. Peter T. Harstad,

State Historical Records Coordinator

Division of the State Historical Society

402 Iowa Ave.

Iowa City, Iowa 52240

$319 / 338-5471$

\section{State Records}

In its first year plan the IHRAB assigns its highest priority to the management of historical records generated by the state. State government touches more lives, more frequently, and in more ways than does any other entity in Iowa. The state has generated and is generating a great variety and number of documents of potential use for historical purposes. Since IHRAB is a creation of state government it has special obligations in this quarter and, hopefully, logicai channels for addressing problems. This plan is submitted in the hope that two agencies of state government, the Iowa State Historical Department, Division of Historical Museum and Archives, and the newly created Records Management Office will define their roles, coordinate their efforts, and function at high levels of effectiveness. To progress from the status quo, cooperation is earnestly solicited from the above mentioned agencies, their governing boards, the governor's office, and the general assembly.

Within the state archives, priority must be given to the creation of a high level position for a professional archivist. Presently, the state of Iowa does not have on its payroll a professional person whose sole responsibility is the administration of state archives. The IHRAB urges the State Historical Board (governing body of the Iowa State Historical Department) to pursue this priority vigorously in its budgetary request for the next fiscal year. When 
such a position is secured and an able person is hired, the state can begin to find its way back to the enviable position it held in the archival field a half century ago under the leadership of Cassius Stiles. Professionalism is the key to many points that follow concerning state archives. Effective leadership from this position should, in time, have a salutary effect upon the management of the records of other units of government and also stimulate endeavors in the private sector.

In 1974 the Iowa General Assembly established a Records Management Office and a State Records Commission. During recent months this office and commission have worked hard to develop a records management plan to cope with the astounding quantity of paper generated by the state of Iowa. A Records Management Manual has been compiled. Since the manual was prepared without the aid of a professional archivist, procedures must now be instituted to insure that the retention and disposal schedules worked out by the records management staff receive scrutiny for historical purposes.

A close working relationship must be established between the Records Management Office and the state archives. Appointment of a professional archivist is the appropriate solution. Records management people can be counted on to preserve records for administrative purposes; additional measures must be taken to attend to the selection, retention, and care of records for historical purposes. It is imperative that policy makers recognize this distinction.

Because of the budgeting cycle, it is unlikely that a professional archivist can be hired before July 1, 1977. An interim system must therefore be instituted to insure that valuable historical records are not destroyed in the near future. A large quantity of records has been stored indiscriminately in a records storage area. This material is currently being surveyed by the Records Management Office. The destruction of records whose retention period has ended according to the schedules established in the Records Management Manual will begin in September 1976. The IHRAB urges the State Historical Board to take prompt measures to provide professional input before destruction begins. This requires immediate and forceful action.

In months to come, consideration might be given to a grant proposal which would provide a historical review of the Records Management Manual by experienced professional archivists.

Early concerns of an archivist will of necessity be endangered historical records and public access to archival materials. Thought must also be devoted to intermediate and long range planning for a professional staff, for equipment, and for suitable archival space. Especially in the planning stages the archivist should be encouraged to stimulate the thought and raise the horizons of appropriate Iowa policy makers. To this end it may be desirable to seek grant monies from sources outside of state government.

The IHRAB is cognizant that the State Historical Board requested money from the last general assembly for a study of the spatial needs of the Division 
of Historical Museum and Archives. The sum was not appropriated, but the IHRAB urges the State Historical Board to renew its request and offers its assistance in pressing for this goal. But in so doing, it asks the latter board to clarify its concept of how the state archives should ideally relate to the other components of the division and the department. Such planning must be done before an architect is engaged. When the latter step is taken, a building should be designed to accommodate its intended use. Archival materials require a different type of facility than do library or museum materials. Therefore, an experienced archivist should have early and frequent input into the planning of archival facilities.

\section{Records of Counties and Local Units of Government}

Just as many 19th century county court houses and municipal buildings are in danger of destruction, so are the records housed within them. Plans should be made for the preservation of historically valuable local records as one part of a total records program for the state. In the late 1930s WPA workers provided detailed inventories of the records of nine Iowa counties. In at least one of these counties the WPA guide is no longer an accurate guide to extant pre-1940 records. Destruction has taken a heavy toll.

Presently, microfilm crews from The Church of Jesus Christ of Latter Day Saints are filming pre-1900 court house records of interest to genealogists. The microfilming is being done under the auspices of the Heritage committee of the Iowa American Revolution Bicentennial Commission. Interest which has been aroused by this project should be used to good advantage by the IHRAB. There is some danger that records which have not been filmed by the LDS crews may be disposed of by county officials who decide that all records of importance are now on microfilm.

Some county historical societies have assumed temporary control of county records in order to prevent their destruction. The Shelby and Cherokee county historical societies have asked the Iowa State Historical Board and the State Records Coordinator for help. Assistance should be provided, but qualified staff is not available on the state level to help them nor are state funds likely to be forthcoming for this purpose in the near future. As the state archives is revitalized it should be able to provide leadership, example, and, in time, services.

Survey and inventory projects are necessary to shed light on the administration of county records. Grant funds, state appropriations, and money from the private sector must be sought to implement surveys and develop county records programs. Programs devised in other states should be thoroughly investigated and appropriate features adapted into a suitable program for Iowa counties.

While adequate information is being gathered, legislation will be needed to halt the destruction of valuable county and municipal records. Legislation demanding preservation but offering no assistance to county and local gov- 
ernments to maintain a body of records will only frustrate the purposes of preservation. Legislation and funding should provide for staff based at the state archives to consult with county and other governmental officials.

A regional records system may be the answer in Iowa as it has been elsewhere in the nation. In fact, the legislative act which set up the State Historical Department and Board gave the latter body authority to enter into agreements with institutions to provide facilities for regional records centers. Although the provisions are weak and the details are sparse in Iowa law, a regional system should be evaluated as a possible alternative to the present inadequate system.

If insufficient data is available for wise planning for county records, even less is available about municipal records and the records of other units of government. Surveys are needed.

\section{Non-Governmental Records}

Private records or non-governmental records are held in private and public institutions as well as by companies and individuals. In 1940 the Works Project Administration surveyed historical documents in private collections and published $A$ Guide to Manuscript Collections in Iowa. The Heritage Committee of the Iowa American Revolution Bicentennial Commission is currently surveying private records again, but through volunteer effort. This is a worthwhile project which needs coordination with an ongoing state agency. A Guide to Depositories of Manuscript Collections was also prepared by WPA in 1940. Private records in institutions need to be surveyed again also. Private records are defined for the purposes of this plan as personal papers and the records of non-governmental institutions.

Efforts of several manuscript repositories in the state have resulted in the acquisition of substantial collections from the private sector, but care must be taken that collection policies provide for the documentation of many aspects of life in Iowa. To this end, the IHRAB will, during its first year of operation, attempt to identify the major institutions that are collecting manuscripts in the state and will solicit from each a statement of its policies and objectives.

When the above is accomplished, the next logical step is to coordinate collection policies so that certain types of records are not neglected. This will require tact and leadership. There is room for competition, but it is important to provide for the preservation of collections that do not presently have the prestige of the political papers of governmental figures. For example, one repository in Iowa might specialize in the solicitation of business records. The same institution might try to maintain a list of companies that maintain their own archives. School, church and organizational records need to be preserved. Preservation of the visual record, i.e. photographs, should also be given some consideration.

There is enough challenge connected with records generated in the pri- 
vate sector to utilize the full energies of all institutions and individuals in Iowa with an interest in historical records.

\section{Iowa Historical Records Advisory Board Members}

Leslie W. Dunlap, Dean, University Libraries, Vice-chairman of Board; Joyce Giaquinta, Manuscript Librarian, Division of the State Historical Society; Arthur Hielkema, Director of Ramaker Library, Northwestern College; Keach Johnson, Professor of History, Drake University; Jack W. Musgrove, Director, Division of Historical Museum and Archives; Patti O'Dell, Instructor in Genealogy; Glenda Riley, Associate Professor of History, University of Northern Iowa; Thomas Thalken, Director, Herbert Hoover Presidential Library; Richard H. Thomas, Chairman, State Historical Board, Professor, Cornell College; Helen M. Virden, Member, State Historical Board, former county recorder; Stanley Yates, Head, Special Collections Department, Iowa State University; Peter T. Harstad, State Historical Records Coordinator, Director, Division of the State Historical Society.

\section{The Iowa Historical Materials Preservation Society}

IHMPS was formed on September 18, 1976 at an organizational meeting in Ames. The Society is comprised of archivists, manuscript and museum curators, historians, genealogists, records managers, librarians and members of county and local historical societies.

The concerns of IHMPS are (not necessarily in order of priority):

1. Educational Functions: A) Identification and preservation of records in state, county and local agencies; B) Development of the state records plan by the Iowa Historical Records Advisory Board; C) Education of and assistance to county officials, legislators, those individuals maintaining records and those using records. This will be accomplished by meetings, workshops and seminars, a newsletter, and through working with other groups such as the Midwest Archives Conference, American Association for State and Local History, Iowa Local Historical and Museum Association, and Questers; and D) Assisting members with grant proposals.

2. Lobbying Activities: A) Establishment of a State Archivist position; B) Increase of qualified staff in the state archives; C) Construction of a state archives building; and D) Preservation of historically valuable materials scheduled for disposal.

For more information contact the president of IHMPS, Toby Fishbein, Archivist, Iowa State University, Ames, Iowa 50010 
Copyright of Annals of Iowa is the property of State of Iowa, by \& through the State Historical Society of Iowa and its content may not be copied or emailed to multiple sites or posted to a listserv without the copyright holder's express written permission. However, users may print, download, or email articles for individual use. 